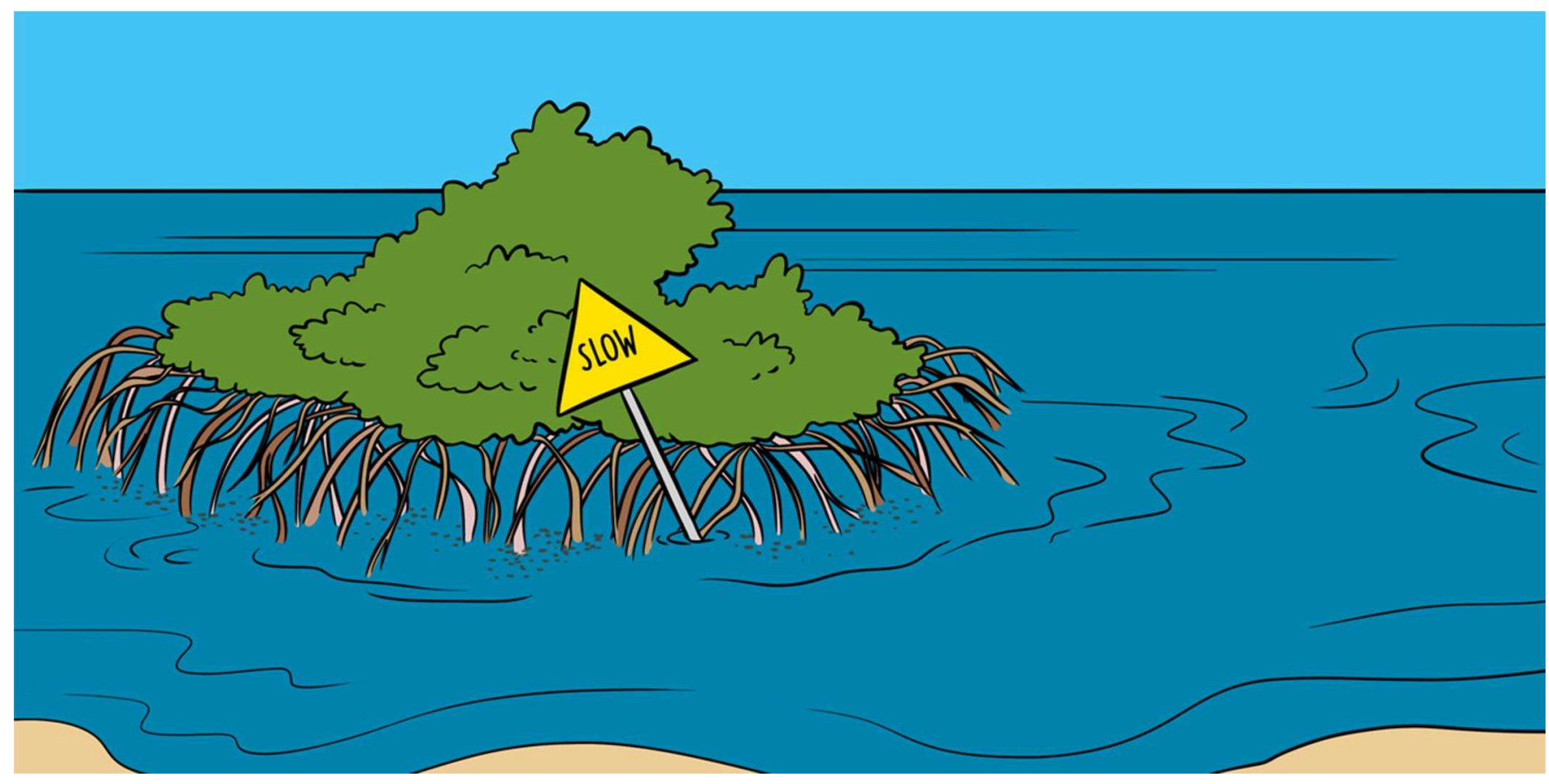

\title{
HOW SEAGRASSES SECURE OUR COASTLINES
}

\section{Marco Fusi ${ }^{1,2^{*}}$ and Daniele Daffonchio ${ }^{1}$}

${ }^{1}$ Red Sea Research Center, King Abdullah University of Science and Technology, Thuwal, Saudi Arabia

${ }^{2}$ School of Applied Sciences, Edinburgh Napier University, Edinburgh, United Kingdom

\section{YOUNG REVIEWERS:}

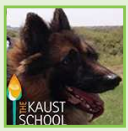

ARNAB

AGE: 14
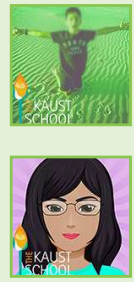

MALSHI

AGE: 12

SAVANA

AGE: 13

SUBHAAN

AGE: 13

ZIA

AGE: 12
Seagrass meadows are hidden underwater grass fields that protect the coast and offer shelter to many sea creatures. Seagrasses are flowering plants that evolved from the land back to the sea, and they now occupy the sea bottom in shallow waters along the coast all over the world. Human activities, such as fishing methods that rely on heavy nets that are dragged across the sea floor, put this important ecosystem at serious risk. In this study, we aimed to measure how seagrasses contribute to coast protection by trapping rock debris transported by the sea. Seagrasses reduce erosion of the coast and protect our houses and cities from both the force of the sea and from sea-level rise caused by global warming. Seagrasses do this by softening the force of the waves with their leaves, and helping sediment transported in the seawater to accumulate on the seafloor. 
Figure 1

(A) In this drawing of seagrass plants, the major structures of the plants are labeled. (B) Seagrasses of the species Enhalus acoroides, one of the most abundant species in the Red Sea. (C) Female flower of Enhalus acoroides that emerged during low tide. Just like other flowering plants, seagrasses generate fruits and seeds.

\section{SEDIMENT}

Sediment is the accumulation of sand, clay, rock debris and dirt that settles in the bottom of lakes, river, and sea.

\section{RHIZOME}

Horizontal underground plant part that can produce the shoot and root systems of a new plant.

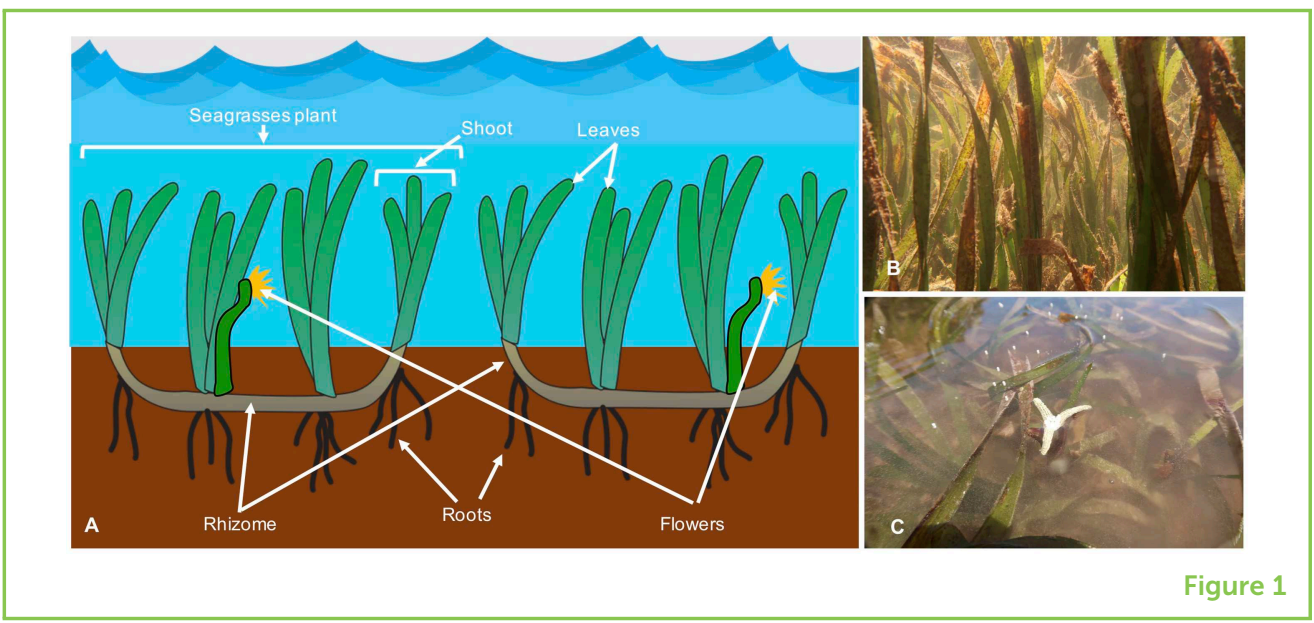

\section{SEAGRASSES: MARINE PLANTS THAT EVOLVED BACK TO THE SEA}

When we speak about ecosystems that thrive on the coast, we often think about beautiful mangrove forests or endless coral reefs. However, we tend to forget that coasts are inhabited by other kinds of species that form an important ecosystem: seagrass meadows.

Seagrasses, like mangrove trees, are flowering plants that evolved from the land back to life in the sea, about 100 million years ago [1]. As with all flowering plants (also known as angiosperms, from the Greek words angeion, "case," and sperma, "seed"), seagrasses usually flower once per year during their reproductive season, the same way many plants on land do during the spring. Instead of using bees or other insects for pollination, seagrasses use marine creatures - like crabs, sea worms, or shrimp-that live burrowed in the sediment amongst seagrass roots [2]. These sea creatures walk and swim among the male flowers of seagrasses and get pollen attached to the spiny and hairy parts of their bodies. When these creatures then walk and swim among the female flowers, the plant is pollinated [2].

Like many other kinds of grasses on land, seagrasses are connected by underground structures called rhizomes, which are similar to roots that grow underneath the sediment. New shoots of seagrasses can sprout up from rhizomes (Figure 1), and a single plant can sprout many shoots over a long period of time. In the Mediterranean Sea, for example, one plant has been found to be more than 200,000 years old-almost as old as our first Homo sapiens ancestor!

All over the world, seagrasses have been estimated to cover between 0.15 and 4.6 million square kilometers [3], an area ten times bigger than the Red Sea. The Red Sea itself hosts 12 of the 60 species of seagrasses present all over the world, and together these seagrasses form an area that extends for more than 100,000 square kilometers, similar the total size of Portugal. 
Figure 2

SECP methods for measuring sediment. Six metal rods of $1.4 \mathrm{~m}$ in length were inserted into the sediment, leaving $20 \mathrm{~cm}$ of the rods uncovered. The distance measured between the sediment and the rods allow us to quickly judge the amount of sediment erosion/accumulation on the plot.

\section{SEDIMENTATION}

The accumulation of sand, clay, rock debris, and dirt that settles on the bottom of lakes, river, and sea.

\section{EROSION}

The gradual destruction or reduction of sediment.

\section{SECP}

Surface Elevation Change Pins (SECP) is a technique that is used to assess the change in the elevation of the seafloor.

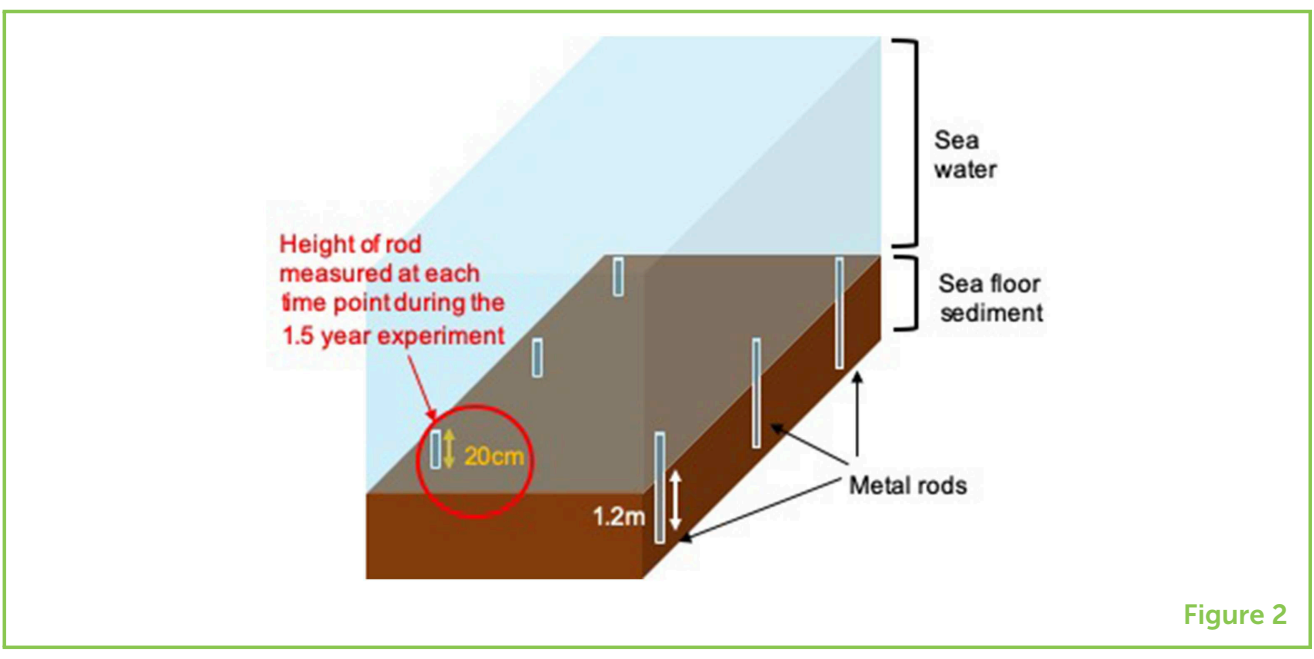

\section{SEAGRASSES PROTECT THE RED SEA COAST}

Seagrass meadows, with their leaves extending toward the seawater surface, slow down the marine currents that transport sediment and other particles and allow the settling of this sediment among the roots and leaves of the seagrass. By doing this, seagrasses help to form new layers of sediment on top of the older ones. But how do seagrasses avoid being buried? The trick is in their extraordinary level of adaptation, acquired by living in this constantly changing ecosystem: thanks to rhizomes, each single seagrass plant can adjust its growth and keep pace with sedimentation. By helping sediment to accumulate, seagrasses protect the coastline from erosion and therefore protect houses, roads, and cities built near the shore.

To find out how much sediment seagrasses trap, we set up a measuring system that used six metal rods, following a method called surface elevation change pin (SECP). SECP is used by many scientists to measure the sediment gathered in mangrove forests and saltmarshes (Figure 2).

We established five experimental plots on the sea bottom within seagrass meadows and five in sediment not covered by seagrasses. At the time of the set-up, the rods were firmly secured into the sea floor $1.2 \mathrm{~m}$ deep, leaving $20 \mathrm{~cm}$ of the rods protruding above the sediment. Over a monitoring period of one and a half years, we checked on the rods three times. For each time point, we measured the height of the metal rods that remained uncovered on the surface of the sediment. If sediment had accumulated between the installation of the rods and our first check, the distance from the tip of the rod to the seafloor would be $<20 \mathrm{~cm}$, but, in the case of erosion, the distance would be more than $20 \mathrm{~cm}$. We used the lengths of each of the six rods to calculate the average accumulation/erosion of sediment in each experimental plot. At the end of the monitoring, we were able to conclude that, along the Central Red Sea at the 
Figure 3

Seagrasses help to trap sediment particles transported by sea currents. The leaves, extending toward the sea surface, slow down the water currents. The slower current is not able to carry the particles of sediment, so the particles drop down and become part of the seafloor. eventually building it up. When seagrasses are not present, the sea current has no obstacles and carries the sediment particles away, lifting them up and eroding the seafloor.

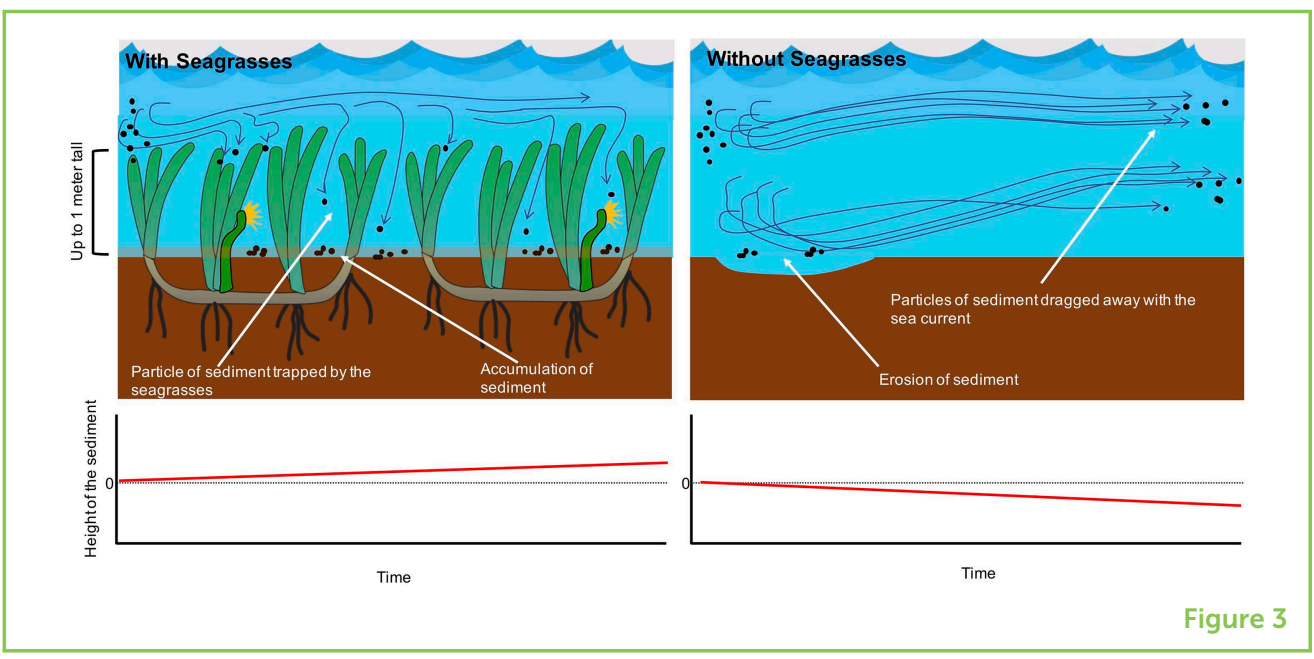

Saudi Arabian coast, seagrasses helped to accumulate sediment, with a sediment accumulation rate of $7.84 \mathrm{~mm}$ per year, while in the areas not covered by seagrasses, we saw sediment loss (erosion) of $30.9 \mathrm{~mm}$ per year (Figure 3).

This experiment was repeated in several other locations all over the world and similar results were found. In Kenya, for example, we recorded a sediment accumulation of $34 \mathrm{~mm}$ per year in seagrass meadows. On the other hand, erosion in areas not covered by seagrasses accounted for a loss of up to $40 \mathrm{~mm}$ of sediment per year in Tanzania, and an average loss of $30 \mathrm{~mm}$ per year in Kenya. This data clearly shows us how important seagrasses are for holding the sediment in coastal areas, and therefore tells us that we urgently need to establish coastal management laws to protect seagrass meadows.

Coastlines all over the world are full of people. Many cities, resorts, and villages are constructed along the coast and often the risk of coastal erosion caused by this construction is not considered. Also, in the last few decades, human activities, such as the construction of dams along rivers has limited the amount of sediment coming into the sea. The reduced input of sediment has resulted in increased erosion of beaches and rocky shores by the ocean currents. This erosion has resulted in dramatic destruction of buildings. Seagrasses are natural friends that can help to solve this problem.

In summary, seagrass meadows are one of the most effective barriers against erosion, because they trap sediment amongst their leaves. Archaeologists have learned from seagrasses how to protect underwater archaeological sites, like a site in Denmark where dozens of ancient Roman and Viking shipwrecks have been discovered. The archaeologists use seagrass-like covers as sediment traps, to build up sediment so that it buries the ships. Burial creates low-oxygen conditions and keeps the wood from rotting [4]. 
Figure 4

(A) Seagrass meadow.

(B) Small animals, such as tunicates and bryozoans, can live attached to seagrass leaves. Tunicates are marine animals with hard outer shells and bryozoans are moss-like marine animals. Both animals feed by filtering food from seawater. (C) Blue-spotted sting ray, an animal frequently encountered in seagrass meadows.

\section{BIODIVERSITY}

All the big and small animals, plants bacteria, and fungi of the world or of a particular ecosystem like seagrasses, coral reefs, rainforests, mountains, deserts, and many others.

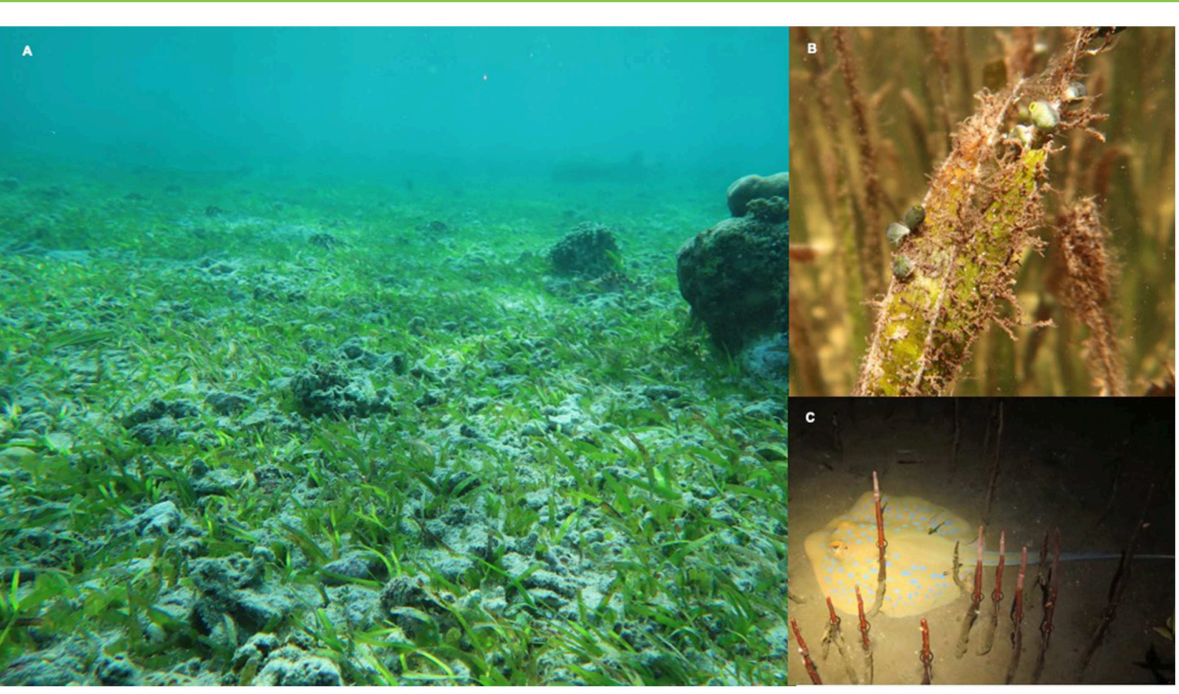

Figure 4

\section{SEAGRASSES PROTECT BIODIVERSITY AND KEEP THE COAST CLEAN}

Seagrasses do not resemble the colorful and magnificent coral reefs, but they can have the same high level of marine biodiversity. During each dive into seagrass meadows in the Red Sea, we can have amazing encounters. We might bump into a curious blue-spotted ray in search of food, or a very annoyed mantis shrimp that is scared by inquisitive scientists. Octopi, cuttlefishes, and other fishes observe us at a distance. We discovered that Red Sea seagrasses host more than 60 animal burrows per square meter. Crabs, shrimp, bivalves, and fishes find shelter among seagrass rhizomes. Moreover, many little animals, such as bryozoans, tunicates, sponges, and sea worms, anchor themselves to the leaves or the exposed roots of seagrasses (Figure 4). Scientists have recently discovered that the cooperation between seagrasses and animals results in a strong protection of the coast from organisms that cause diseases [5]. Seagrasses have been demonstrated to produce natural compounds that kill the bacteria that bring illnesses to fishes and to us.

Our study highlights the importance of the seagrass ecosystems in the sea. The next question to answer is, "How do we secure the survival of seagrasses in the future of the Red Sea?" Seagrasses are in danger because of the many human activities going on along the coast. Fishing methods that rely on heavy nets that are dragged across the sea floor eradicate and kill these plants as wells as the fast growing city waterfronts pollute the coastal water by uncontrolled wastewater discharge and block the ground freshwater going into the sea, provoking the death of this important ecosystem. Is our duty continue to study the seagrasses ecosystem to seek solutions to make the 
human being live end thrive together with the seagrasses by changing fishing methods and by designing environmental friendly cities.

\section{ORIGINAL SOURCE ARTICLE}

Potouroglou, M., Bull, J. C., Krauss, K. W., Kennedy, H. A., Fusi, M., Daffonchio, D., et al. 2017. Measuring the role of seagrasses in regulating sediment surface elevation. Sci. Rep. 7:11917. doi: 10.1038/s41598-017-12354-y

\section{REFERENCES}

1. Larkum, A. W. D., Orth, R. J., and Duarte, C. M. 2006. Seagrasses. Dordrecht: Springer.

2. Van Tussenbroek, B. I., Villamil, N., Márquez-Guzmán, J., Wong, R., Monroy-Velázquez, L. V., and Solis-Weiss, V. 2016. Experimental evidence of pollination in marine flowers by invertebrate fauna. Nat. Commun. 7:12980. doi: $10.1038 /$ ncomms12980

3. Duarte, C. M. 2017. Reviews and syntheses: hidden forests, the role of vegetated coastal habitats in the ocean carbon budget. Biogeosciences 14:301. doi: $10.5194 / \mathrm{bg}-14-301-2017$

4. Gregory, D., Jensen, P., and Strætkvern, K. 2012. Conservation and in situ preservation of wooden shipwrecks from marine environments. J. Cult. Herit. 13:S139-48. doi: 10.1016/j.culher.2012.03.005

5. Lamb, J. B., van de Water, J. A., Bourne, D. G., Altier, C., Hein, M. Y., Fiorenza, E. A., et al. 2017. Seagrass ecosystems reduce exposure to bacterial pathogens of humans, fishes, and invertebrates. Science 355:731-3. doi: 10.1126/science.aal1956

SUBMITTED: 31 March 2019; ACCEPTED: 15 August 2019;

PUBLISHED ONLINE: 16 September 2019.

EDITED BY: Rúben Martins Costa, King Abdullah University of Science and Technology, Saudi Arabia

CITATION: Fusi M and Daffonchio D (2019) How Seagrasses Secure Our Coastlines. Front. Young Minds 7:114. doi: 10.3389/frym.2019.00114

CONFLICT OF INTEREST STATEMENT: The authors declare that the research was conducted in the absence of any commercial or financial relationships that could be construed as a potential conflict of interest.

COPYRIGHT @ 2019 Fusi and Daffonchio. This is an open-access article distributed under the terms of the Creative Commons Attribution License (CC BY). The use, distribution or reproduction in other forums is permitted, provided the original author(s) and the copyright owner(s) are credited and that the original publication in this journal is cited, in accordance with accepted academic practice. No use, distribution or reproduction is permitted which does not comply with these terms. 

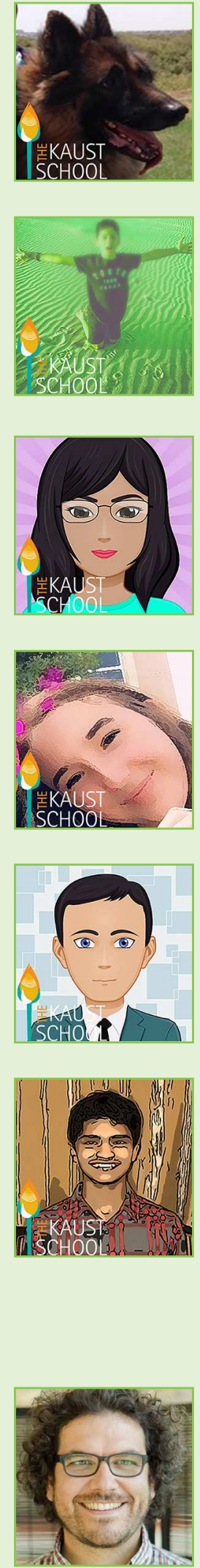

\section{YOUNG REVIEWERS}

\section{ARNAB, AGE: 14}

I am a 14 years old student who likes computers and other tech related items. I like building stuff with lego as well as doing science. I also like video games, Cities Skylines, and Mario.

\section{FABIAN, AGE: 12}

Fabián is a world traveling, 12 years old, seventh grade polyglot who loves the ocean and being creative. His hobbies are: mountain biking, lego, inventing, acting, and reading, but especially reading. He loves being a part of the Frontiers for Young Minds program and looks forward to next year!

\section{MALSHI, AGE: 12}

My name is Malshi, and I am 12 years old. I like Science and Math and I am interested in Chemistry. I love reading in my spare time and I love playing the piano. My favorite sport is badminton and in the future, I want to be a scientist.

\section{SAVANA, AGE: 13}

I love dogs, my favorite color is red, and I love hanging out with my friends.

\section{SUBHAAN, AGE: 13}

I am from Canada and I like memes. I like Marvel and my favorite superhero is Spiderman and my favorite villain is Venom.

\section{ZIA, AGE: 12}

One of my favorite subjects in school in school is science. I am very curious about how the daily things we do in our life happen. I especially like biology and cosmology. I watch a lot of documentaries about space and like to research on my interests.

\section{AUTHORS}

\section{MARCO FUSI}

I grew up in Tuscany, a central region of Italy, developing a strong relationship with the Mediterranean Sea. I always seek adventure in it, fascinated by the diversity of its thriving species. I started studying computer science, but I always looked forward to turning my work in something useful for the environment and the sea. So, I started my study in natural sciences at the University of Florence in Italy and I immediately volunteer in many projects involving the sea. This led me to travel across the Indian Ocean, studying mangrove and mangrove crabs with my Master and my Ph.D. and afterward to complete a 5 years of Post-Doctorate 


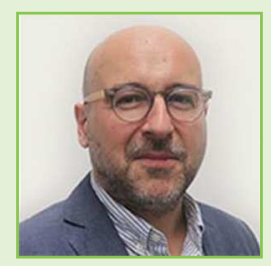

research fellow in Saudi Arabia where I extend my work to seagrasses and coral reef.

*marco.fusi@kaust.edu.sa

\section{DANIELE DAFFONCHIO}

Prof. Daffonchio has developed research on the exploration and characterization of bacteria living in and extreme marine and terrestrial environments. He is actually dealing with the study and microorganisms along the water stress continuity from the Arabian Desert to the depth of the brine pools in the Red Sea. A particular focus is on the bacteria-host symbiosis with plants and animals in mangrove, seagrasses, and desert environments. 